\title{
Gelatinized and Nongelatinized Corn Starch/ Poly( $\varepsilon$-Caprolactone) Blends: Characterization by Rheological, Mechanical and Morphological Properties
}

\author{
Derval S. Rosa, Cristina G. F. Guedes, Andréa G. Pedroso \\ Universidade São Francisco, Itatiba, SP
}

\begin{abstract}
Poly(E-caprolactone)/corn starch blends containing 25, 50 and 75 wt.\% starch were prepared by mechanical processing and characterized by the melt flow index (MFI), tensile test and scanning electron microscopy (SEM). For comparison, starch was used in gelatinized and nongelatinized forms and was also characterized by viscography. The addition of starch to poly( $\varepsilon$-caprolactone) reduced the MFI values, the tensile strength and the elongation at break, whereas the modulus increased. The reductions in the MFI and tensile properties were most evident when gelatinized starch was used. Viscography and SEM showed that starch was well gelatinized by the gelatinization process. Blends containing nongelatinized starch showed a good dispersion of starch but poor interfacial interactions.
\end{abstract}

Keywords: Biodegradable polymers, gelatinization, polymer blends, poly(E-caprolactone), starch.

\section{Introduction}

In recent years, concern about the filling up of landfills with non-degradable materials such as plastics has increased. This concern has led to the development of recycling techniques and to the use of alternative biodegradable materials. Poly( $\varepsilon$-caprolactone) (PCL) is a biodegradable, highly flexible, aliphatic polyester ${ }^{[1,2]}$ produced by the ring opening polymerization of $\varepsilon$-caprolactone ${ }^{[3]}$. The use of PCL is limited by its high cost, mainly because the low melting point $\left(\sim 67^{\circ} \mathrm{C}\right)$ makes it difficult to process PCL by conventional techniques used for thermoplastic materials. However, this problem can be overcome by blending PCL with $\operatorname{starch}^{[3]}$, an inexpensive, biodegradable polysaccharide.

In recent years, many attempts have focused on blending plastic materials with cheap and natural polymers, such as starch, to create new materials with specific properties ${ }^{[4-6]}$. Koenig and Huang ${ }^{[6]}$ evaluated PCL blends containing 25 wt.\% high-amylose corn starch (HA-CS) and waxy corn starch granules based on tensile testing and concluded that the tensile strength of PCL/HA-CS blends was $15 \%$ lower than for PCL. However, these authors did not discuss the influence of the structure of starch on the properties studied. $\mathrm{Wu}^{[4]}$ and Mani et al. ${ }^{[7]}$ observed that the mechanical and thermal properties of PCL became noticeably worse when this polymer was blended with starch, mainly because of the poor compatibility between the two phases.

Starch granules are partially crystalline particles and are composed mainly of linear D-glucan amylose and highly branched amylopectin polymers ${ }^{[8]}$. However, the poor melting properties of native starch mean that before being used in PCL/starch blends, the starch must be converted into an essentially amorphous, homogeneous material suitable for thermoplastic processing ${ }^{[9]}$. Starch plastification is commonly done by extrusion at 120 $220{ }^{\circ} \mathrm{C}^{[2]}$.

Starch gelatinization involves melting the polymer in an aqueous medium. When a water-starch suspension is heated, the starch undergoes a phase transition between 60 and $70{ }^{\circ} \mathrm{C}$. Granule swelling increases with temperature and becomes irreversible when gelatinization occurs. The swelling corresponds to a mass transfer of bulk water in the suspension to water associated with starch components (amylose and amylopectin). The granule structure is generally dispersed when heat treatment reaches a certain level, and the solubilization of amylose chains leads to an increase in viscosity ${ }^{[10]}$. This change in viscosity is manifested by irreversible changes in properties such as the disruption of the semicrystalline structure, seen as a loss of birefringence, and starch solubilization. The phenomenon that follows gelatinization during the dissolution of starch and eventually leads to the total disruption of the granules is known as pasting ${ }^{[11]}$. During the cooling phase, the starch undergoes retrogradation in which the starch chains begin to reassociate in an ordered structure, and this is accompanied by another rise in viscosity, usually referred to as setback.

In this study, we compared the effect of gelatinized and nongelatinized starch on the mechanical properties, melt flow index and morphology of PCL/starch blends containing 25,50 and $75 \mathrm{wt} . \%$ starch.

Autor para correspondência: Derval S. Rosa, Universidade São Francisco, Programa de Pós-Graduação Stricto Sensu em Engenharia e Ciência dos Materiais, Laboratório de Polímeros Biodegradáveis e Soluções Ambientais, Rua Alexandre Rodrigues Barbosa 45 - centro, CEP: 13251-900, Itatiba, SP. Email:derval.rosa@saofrancisco.edu.br 


\section{Experimental}

\section{Materials}

PCL (Tone P-767) was supplied in pellet form by Union Chemical Carbide Ltd. (Cubatão, SP, Brazil), and had a melting index of $7.0 \mathrm{~g} / 10 \mathrm{~min}\left(125^{\circ} \mathrm{C} / 2.16 \mathrm{~kg}\right)$ (ASTM $\mathrm{D}-1238)$, a density of $1.145 \mathrm{~g} / \mathrm{cm}^{3}$ and a number average molecular weight $\left(\mathrm{M}_{\mathrm{n}}\right)$ of $50,000 \mathrm{~g} / \mathrm{mol}$.

Corn starch (Amidex 3001) was supplied in powder form by Corn Products Brazil - Ingredientes Industriais Ltda. (Jundiaí, SP, Brazil), and contained 27 wt.\% amylose and 73 wt. $\%$ amylopectin, with a number average molecular weight $\left(\mathrm{M}_{\mathrm{n}}\right)$ of $486,000 \mathrm{~g} / \mathrm{mol}$.

\section{Starch gelatinization}

Gelatinization was done using a starch suspension (10 wt.\% starch and $90 \mathrm{wt} . \%$ distilled water) that was heated at a rate of $1.5^{\circ} \mathrm{C} \cdot \mathrm{min}^{-1}$, from $50{ }^{\circ} \mathrm{C}$ to $95{ }^{\circ} \mathrm{C}$, and then held at the latter temperature for approximately $20 \mathrm{~min}$. The mixture was then cooled to room temperature $\left(24 \pm 3{ }^{\circ} \mathrm{C}\right)$ at a rate of $1.5^{\circ} \mathrm{C} \cdot \mathrm{min}^{-1}$, dried at $90^{\circ} \mathrm{C}$ in an oven with circulating air, and ground in a Croton type TE-625 rotatory blade mill (Tecnal, São Paulo, SP, Brazil). The starch gelatinization was monitored using a Brabender viscograph (OHG Duisburg, Germany) operated at $75 \mathrm{rpm}$, which recorded torque against time. Gelatinized starch was stored at $25^{\circ} \mathrm{C}$ for 7 days prior to blend preparation.

\section{Blend preparation}

Blends containing 25,50 or 75 wt. $\%$ starch were prepared in an MH-100 homogenizer (MH Equipamento Ltda., SP, Brazil) operated at 1,880/3,600 rpm. The starch was dried in an oven at $60{ }^{\circ} \mathrm{C}$ for $1 \mathrm{~h}$ before mixing the components and placing them in the homogenizer.

\section{Molding}

Pure PCL and the blends were compression molded into sheets (180 mm x $180 \mathrm{~mm}$ x $2 \mathrm{~mm}$ ) using a model MA 098 Marconi Press (Marconi Equipamentos e Calibração para Laboratórios, Piracicaba, SP, Brazil). The mold containing the desired material (PCL or blend) was initially placed in the press and heated for 5 min without applying any pressure in order to ensure uniform heat flow through the material. For all of the blends, the temperature was kept at $110 \pm 5^{\circ} \mathrm{C}$ for $5 \mathrm{~min}$ at $5 \mathrm{t}$. The resulting sheets were removed from the press after cooling to room temperature. These sheets were maintained at $25^{\circ} \mathrm{C}$ for 7 days prior to characterization.

\section{Melt flow index (MFI)}

MFI measurements of PCL and the blends were performed using a model MI-1 plastometer (DSM Instrumentação Científica Ltda., São Paulo, SP, Brazil), according to ASTM D1238 (procedure A, $125^{\circ} \mathrm{C} / 2.16 \mathrm{~kg}$ ).

\section{Tensile properties}

The tensile properties were assessed with an EMIC model DL 2000 universal testing machine (EMIC Equipamentos e
Sistemas de Ensaio Ltda., São José dos Pinhais, PR, Brazil) using specimens (Type IV) cut from compression-molded sheets, according to the ASTM D-638 standard. The control program used was Mtest LBP version 3.00 and the load cell had a capacity of $2,000 \mathrm{kgf}$. The specimens were initially 25 $\mathrm{mm}$ long and the speed of stretching was $50 \mathrm{~mm} / \mathrm{min}$. The average and standard deviation values of tensile strength, elongation at break and Young's modulus were determined for each formulation.

\section{Scanning electron microscopy (SEM)}

Specimens were fractured after freezing in liquid nitrogen and micrographs of the fracture surfaces were taken using a JEOL model JSM-5900LV scanning electron microscope (JEOL Ltd, Akishima, Japan).

\section{Results and Discussion}

\section{Pasting properties}

Figure 1 shows the pasting curves for nongelatinized and gelatinized starches, with the torque measurements recorded as a viscosity signal. For nongelatinized starch, there was initially an increase in torque at $50-75^{\circ} \mathrm{C}$, indicating swelling of the starch grains (A-B). The swelling of starch granules began in the relatively mobile amorphous region composed of free amylose/amylopectin chains and amylopectin double helices that were not involved in crystal formation, and in the rigid amorphous regions close to branch points but immediately adjacent to crystalline regions. Differences in swelling among native starches have been attributed to an interplay of various factors such as granule size, crystallinity, amylose-lipid complex content, and interaction among starch chains in the amorphous region ${ }^{[12]}$.

Starch gelatinization began at $79^{\circ} \mathrm{C}$, after heating for 20 min, and resulted in an increase in viscosity that reached a maximum torque peak of $494 \mathrm{BU}$ (B) at $90{ }^{\circ} \mathrm{C}$, at which point the suspension became a paste. When heated in sufficient water, starch granules undergo an order-disorder phase transition (gelatinization) that nearly results in solubilization of the starch. This phase transition is associated with the uptake of heat and the diffusion of water into starch granules that leads to granule

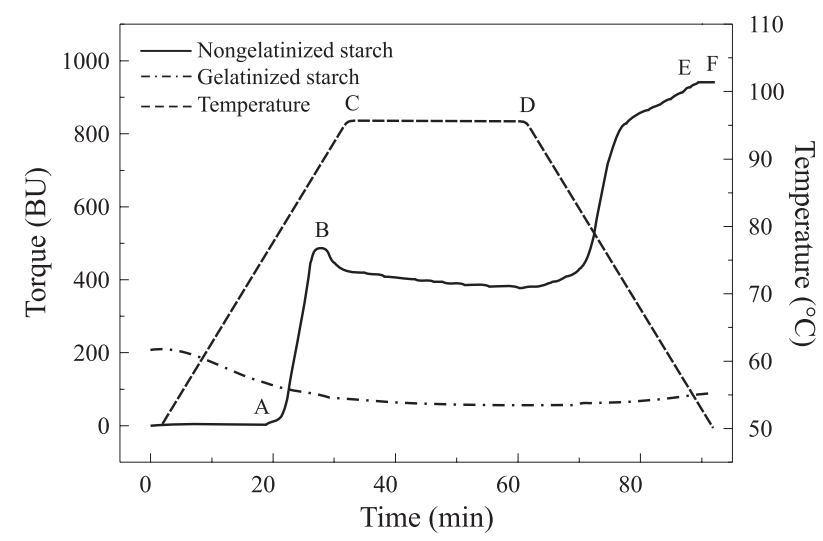

Figure 1. Pasting curves for nongelatinized and gelatinized starch. 
swelling, loss of crystallinity and amylose leaching ${ }^{[12]}$.

The torque at $95^{\circ} \mathrm{C}$, which indicates the ease of cooking $\left[{ }^{[13]}\right.$, was $470 \mathrm{BU}$. The stability of the paste or resistance to breakdown, which reflects the textural stability of the starch gel during cooking/mixing, corresponded to a torque of 391 $\mathrm{BU}$ after cooking for $20 \mathrm{~min}$ at $95^{\circ} \mathrm{C}^{[13]}$. After cooling, when the temperature had reached $50{ }^{\circ} \mathrm{C}$, the torque was $911 \mathrm{BU}$. The setback $(\mathrm{E}-\mathrm{B})$, which corresponds to retrogradation and starch gel formation, had a torque of 520 BU.

The gelatinization curve of previously gelatinized starch showed no increase in torque, indicating that the starch suspension did not vary in viscosity when exposed to changes in temperature. This lack of variation implied that the starch was already quite well gelatinized.

\section{Melt flow index (MFI)}

Figure 2 shows that the MFI for the PCL blends with starch decreased with increasing starch content. Since the MFI is an indirect measurement of viscosity, it follows that the starch must act as a rigid filler, the main effect of which is to increase the elastic modulus of a composite or the viscosity of a fluid suspension ${ }^{[14]}$.

The reductions in the MFI for nongelatinized starch blends were $38 \%$ and $86 \%$ for the blends containing $25 \mathrm{wt} . \%$ and 50 wt.\% starch, respectively, relative to pure PCL. The decrease in MFI was more accentuated, i.e., $50 \%$ and $98 \%$, for the blends containing $25 \mathrm{wt} . \%$ and $50 \mathrm{wt} . \%$ of gelatinized starch, respectively. This decrease in the MFI was a positive indicator since PCL is difficult to process using conventional techniques for thermoplastic materials because of its low melting point $\left(\sim 67^{\circ} \mathrm{C}\right)^{[3]}$ and high MFI at normal processing temperatures. Blends with 75 wt.\% starch were too viscous to be measured.

The gelatinization process reduced the MFI, which suggests that occurred the opening of the grain of the starch and consequently the exposition of the chains of the amylopectin and amylose.

The increase of contact of the ramified chains (amylopectin) with PCL suggests higher interaction between the polymers and consequently a reduction of the MFI.

The opening of the grains changes the behaviour of the action of the starch as reinforcing filler to a ternary blend

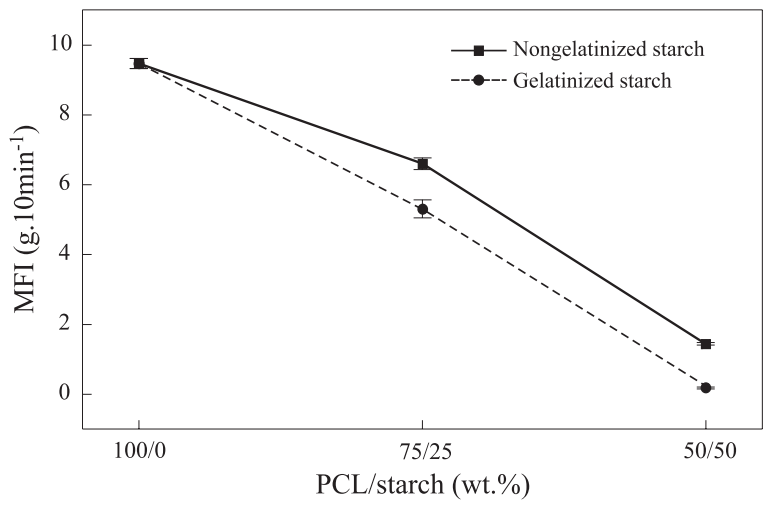

Figure 2. MFI for PCL and PCL/starch blends. The points are the mean \pm S.D. of 10 determinations.
PCL/amylose/amylopectin, which justifies the reduction in the mechanical properties.

\section{Tensile mechanical properties}

Figure 3 shows the tensile strength, elongation at break and Young's modulus values and Figure 4 shows the stress versus strain behaviour for PCL and its blends with starch.

As shown in Figure 3a, tensile strength decreased with increasing starch content, indicating that corn starch behaved as a non-reinforcing filler. The tensile strength decreased $36 \%, 66 \%$ and $88 \%$ for the blends containing 25,50 and 75 wt.\% starch granules, respectively, in relation to pure PCL.
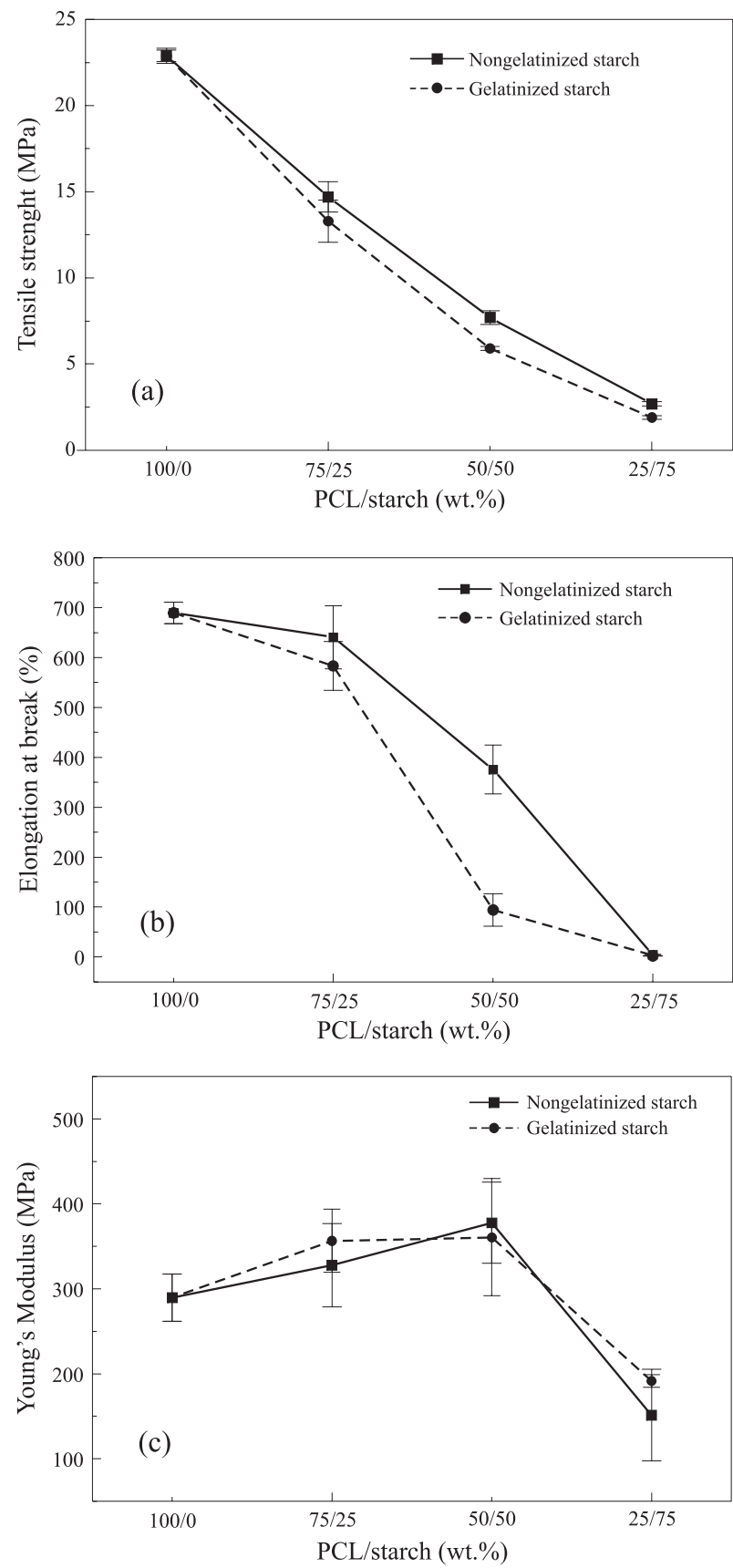

Figure 3. Mechanical properties of PCL and PCL/starch blends: a) Tensile strength. b) Elongation at break. c) Young's modulus. 

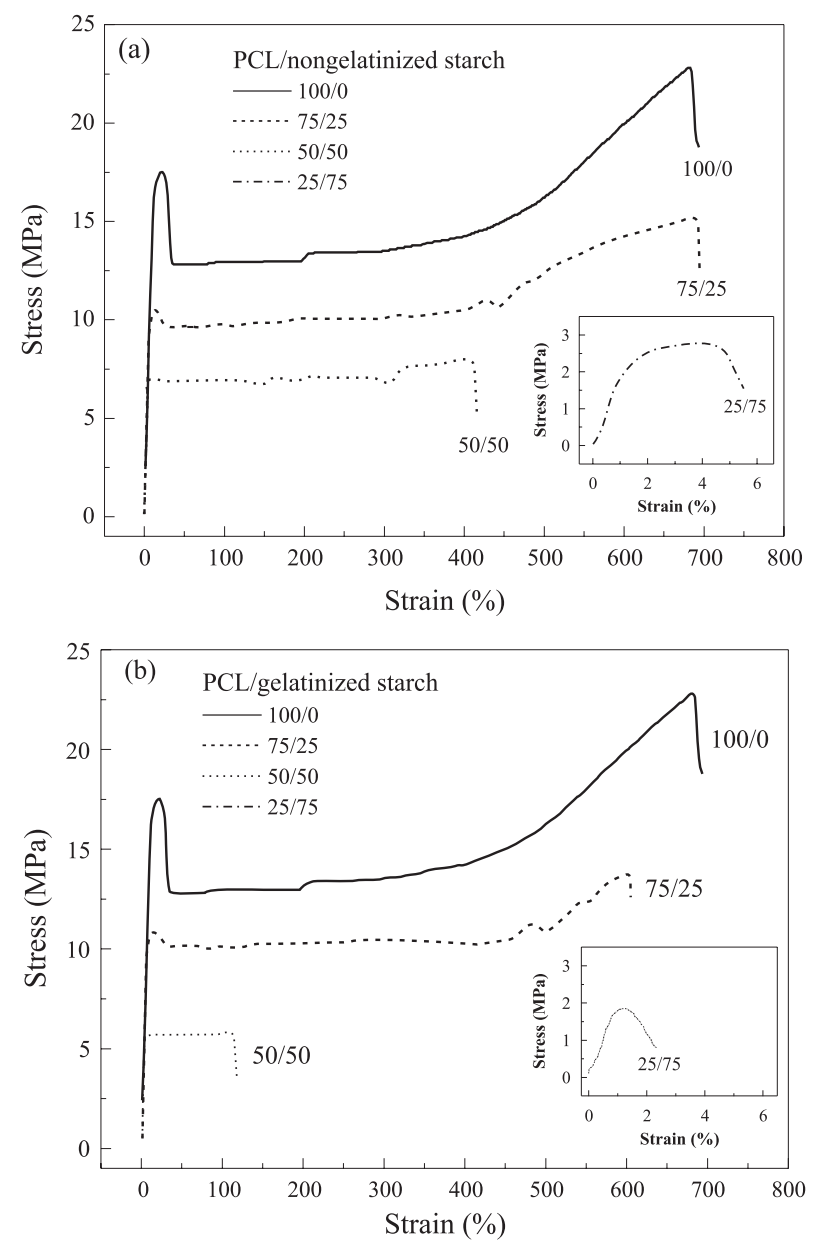

Figure 4. Stress versus strain behaviour of PCL and PCL/starch blends under tension. a) nongelatinized starch. b) gelatinized starch.

The decrease in tensile strength was more accentuated for the blends containing gelatinized starch, that is, decreases of $42 \%, 74 \%$ and $92 \%$ for the blends with 25,50 and $75 \mathrm{wt} . \%$ gelatinized starch, respectively. Ishiaku et $\mathrm{a}^{[15]}$ observed the same behaviour for PCL/sago starch blends and suggested that this effect could be explained by the plasticization and destructuring of starch. In gelatinized starch, the granular structure is destroyed by the gelatinization process, and the starch becomes amorphous. When stress is applied, gelatinized starch (amorphous material) is more easily deformed than nongelatinized starch (granules) and therefore acts as a less rigid filler. This tendency was clearly reflected in Young's modulus, as discussed later.

Figure $3 \mathrm{~b}$ shows that the elongation decreased as the starch content increased. The decrease in elongation at break with rigid fillers reflects the fact that the actual elongation experienced by the polymer matrix is much greater than the measured elongation of the specimen ${ }^{[14]}$. The addition of dry starch granules to PCL follows the general trend for filler effects on polymer properties; i.e., the modulus increases through stiffening of the granules and elongation decreases as the starch content is increased ${ }^{[16]}$.

In synthetic polymer blends, the addition of a second immiscible phase to a ductile matrix material usually significantly diminishes the elongation properties at break.
In many cases, when $20 \%$ of the dispersed minor phase has been added, highly deformable matrix materials are transformed into fragile materials. In synthetic polymer blends with a ductile matrix, the elongation at break is therefore considered to be highly sensitive to the state of the interface ${ }^{[16]}$. However, as shown here, a high elongation at break was maintained when 25 wt.\% nongelatinized starch was added to the PCL since only a $7.1 \%$ decrease was seen compared to pure PCL. Blends containing nongelatinized starch had a significant higher elongation at break than blends containing gelatinized starch only with $50 \mathrm{wt} . \%$ starch.

The values of Young's modulus for the blends (Figure $3 \mathrm{c}$ ) increased slightly with the incorporation of starch, except when $75 \mathrm{wt} . \%$ was added to PCL, in which case there was a significant reduction in this property. In general, modulus is closely related to the hard domain of the material ${ }^{[17]}$. As the starch content increases, the hard domain content increases, as does the tensile modulus of the blend. There was no significant variation in the Young's modulus of any of the blends in which gelatinized or nongelatinized starch was used.

Figure 4 shows that there was little difference in the elongation at break between the samples containing $75 \%$ gelatinized and nongelatinized starch, although the latter had slightly greater values.

\section{Morphology}

Figure 5 shows SEM images of samples of PCL and PCL/ starch. Starch was homogeneously dispersed throughout the polymeric matrix. Nongelatinized starch granules still retained their shape and functioned as rigid particulate fillers. The lack of adhesion between PCL and nongelatinized starch seen on the fracture surfaces indicated a poor interfacial interaction and could explain the decrease in mechanical properties with starch incorporation. As the content of nongelatinized starch increased, filler-filler interactions increased (Figures $5 \mathrm{c}, \mathrm{d}$, $\mathrm{g}, \mathrm{h}, \mathrm{k}, \mathrm{l})$. This could also account for the deteriorating physical properties as the transfer of stress from the matrix to the filler became less effective ${ }^{[15]}$.

Figures $5 \mathrm{e}, \mathrm{f}, \mathrm{i}, \mathrm{j}, \mathrm{m}$ and $\mathrm{n}$ show the thermoplastic nature of gelatinized starch. Native starch granules are typically spherical in shape, with a diameter of 5-25 $\mu \mathrm{m}^{[3,16]}$. Comparison of the size of the granules in the PCL/ nongelatinized starch blends with those present in PCL/ gelatinized starch showed that nongelatinized starch did not undergo significant melting during preparation of the blends. Disruption of the semicrystalline structure of gelatinized starch did not result in a granular structure, as discussed above for the pasting properties. SEM also showed poor interfacial adhesion between PCL and gelatinized starch, which agreed with the results for the mechanical properties.

\section{Conclusions}

The effect of starch on the properties of PCL/starch blends depended on the starch content and morphology. Biodegradable blends of PCL with starch had a higher 


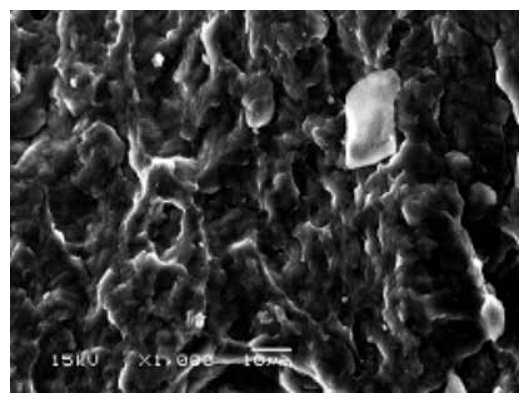

(a)

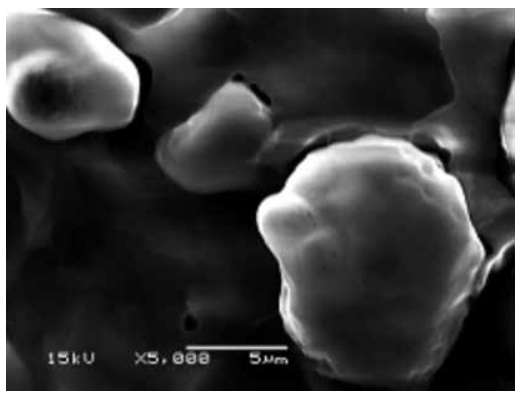

(d)

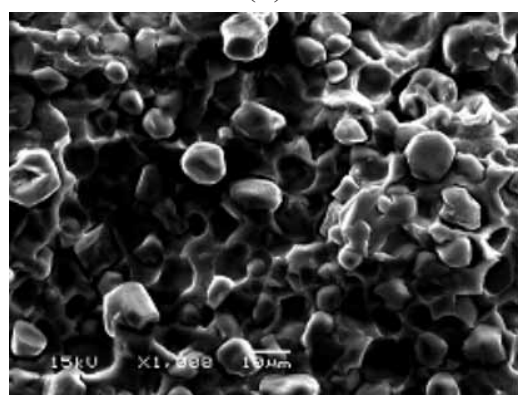

(g)

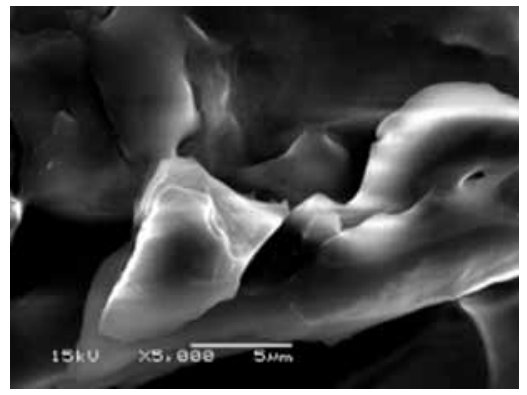

(j)

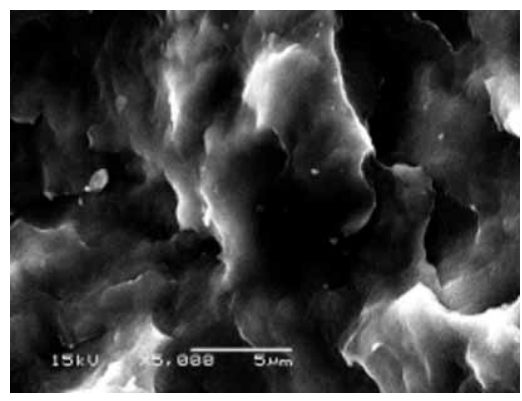

(b)

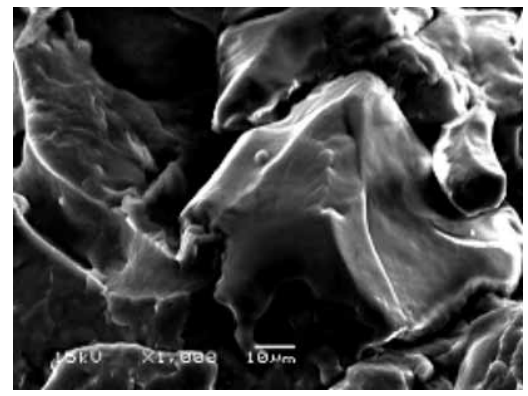

(e)

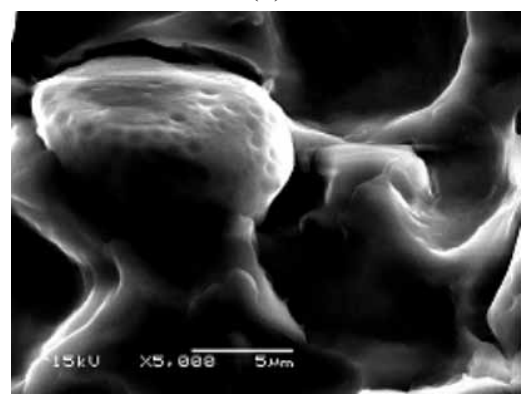

(h)

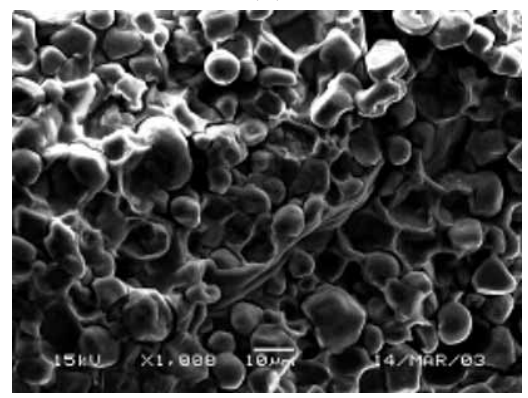

(k)

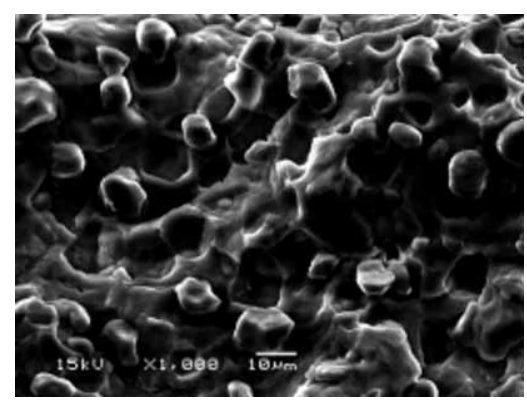

(c)

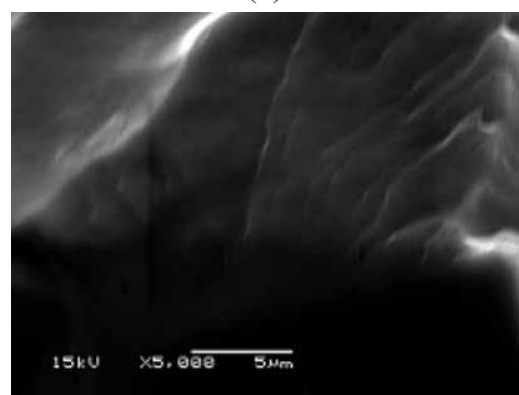

(f)

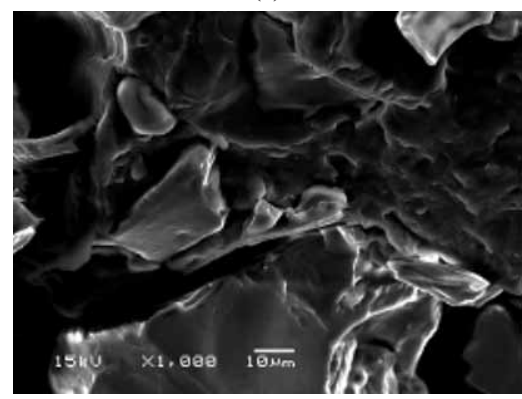

(i)

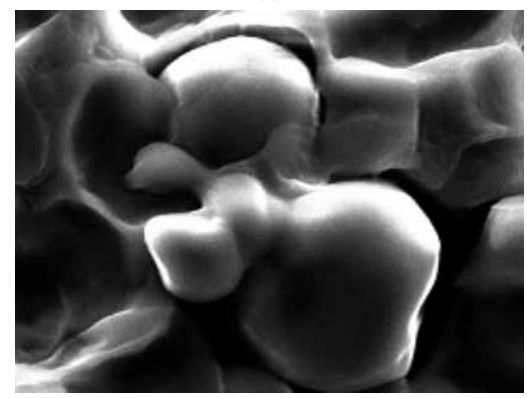

(1)

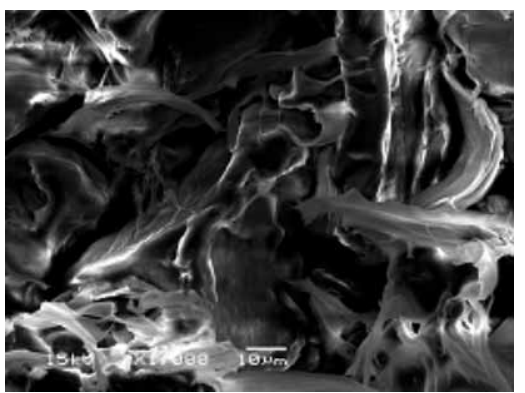

(m)

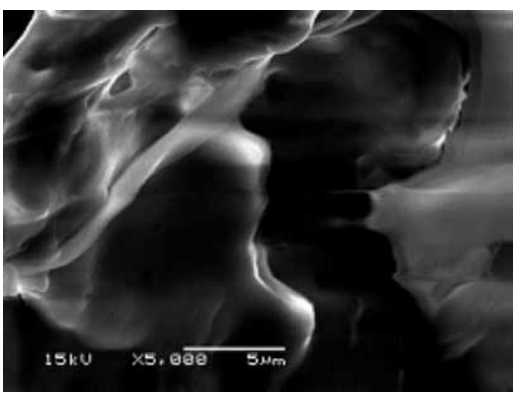

(n)

Figure 5. SEM images of PCL and PCL/starch blends: a) pure PCL (1,000x); b) pure PCL (5,000x); c) 75/25 nongelatinized starch (1,000x); d) 75/25 nongelatinized starch (5,000x); e) 75/25 gelatinized starch (1,000x); f) 75/25 gelatinized starch (5,000x); g) 50/50 nongelatinized starch (1,000x); h) 50/ 50 nongelatinized starch $(5,000 \mathrm{x})$; i) 50/50 gelatinized starch (1,000x); j) 50/50 gelatinized starch (5,000x); k) 25/75 nongelatinized starch (1,000x); 1 ) 25/ 75 nongelatinized starch $(5,000 x) ; \mathrm{m})$ 25/75 gelatinized starch $(1,000 \mathrm{x})$, and n) 25/75 gelatinized starch $(5,000 \mathrm{x})$. 
Young's modulus and lower tensile strength and elongation at break than pure PCL. The blend with 25 wt. $\%$ of nongelatinized starch showed a small decrease in the elongation at break. Gelatinized starch caused a greater reduction in the MFI and tensile strength values compared to nongelatinized starch. Viscography and SEM showed that the gelatinization process was efficient. SEM showed that blends prepared with nongelatinized and gelatinized starch were immiscible, had a good dispersion of starch and did not show interfacial adhesion.

\section{Acknowledgements}

The authors thank Union Chemical Carbide Ltd. and Corn Products Brazil- Ingredientes Industriais Ltda. for supplying the PCL and starch, respectively, and the LME/LNLS at the Laboratório Nacional de Luz Síncrotron (Campinas, SP, Brazil) for technical support. This work was supported by FAPESP (processes 99/10716-4 and 02/06803-3), CNPq (processes 303500/2002-6 and 477942/2003-2), and Universidade São Francisco.

\section{References}

1. Chen D. R.; Bei J. Z.; Wang S. G. - Polym. Degrad. Stab., 67, p.45 (2000).

2. Müller R-J.; Kleeberg I.; Decjker W-D. - J. Biotechnol., 86, p.87 (2001)

3. Matzinos P.; Tserki V.; Gianikouris C.; Pavlidou E.; Panayiotou C. - Eur. Polym. J., 38, p.1713 (2002).

4. Wu C-S. - Polym. Degrad. Stab., 80, p.127 (2003).
5. Rosa D. S., Pantano Filho R. - "Biodegradação: um ensaio com polímeros", Moara Editora e Univ. São Francisco Editora; Itatiba, Bragança Paulista (2003).

6. Koenig M. F.; Huang S. J. - Polym., 36, p.1877 (1995).

7. Mani R.; Bhattacharya M. - Eur. Polym. J., 37, p.515 (2001).

8. Alonso A. G.; Escrig A. J.; Carrón N. M.; Bravo L.; Calixto F. S. - Food Chem., 66, p.181 (1999).

9. Myllarinen P, Buleon A, Lahtinen R, Forssell P. Carbohydrate Polym., 48, p.41 (2002).

10. Douzals J. P.; Marechal P. A.; Coquille J. C.; Gervais P. - J. Agric. Food Chem., 44, p.1403 (1996).

11. Atwell W.A.; Hood L. F.; Lineback D. R.; Varriano-Marston E. and Zobel H. F. - Cereal Foods World, 33, p.306 (1988).

12. Vasanthan T.; Bergthaller W.; Driedger D.; Yeung J.; Sporns P. - Food Res. Int., 32, p.355 (1999).

13. Karim A.A.; Norziah M. H.; Seow C. C. - Food Chem., 71, p.9 (2000).

14. Nielsen L. E. - "Particulate-filled polymers", in: Mechanical properties of polymers and composites, cap. 7, Marcel Dekker Inc., New York (1974).

15. Ishiaku U. S.; Pang K. W.; Lee W. S.; Ishak Z. A. M. Eur. Polym. J., 38, p.393 (2002).

16. St-Pierre N.; Favis B. D.; Ramsay B. A.; Ramsay J. A.; Verhoogt H. - Polym., 38, p.647 (1997).

17. Jang B.C.; Huh S. Y.; Jang J. G.; Bae Y. C. - J. Appl. Polym. Sci., 82, p.3313 (2001).

Enviado: $15 / 12 / 03$ Reenviado: 07/04/04 Aprovado: 18/05/04 